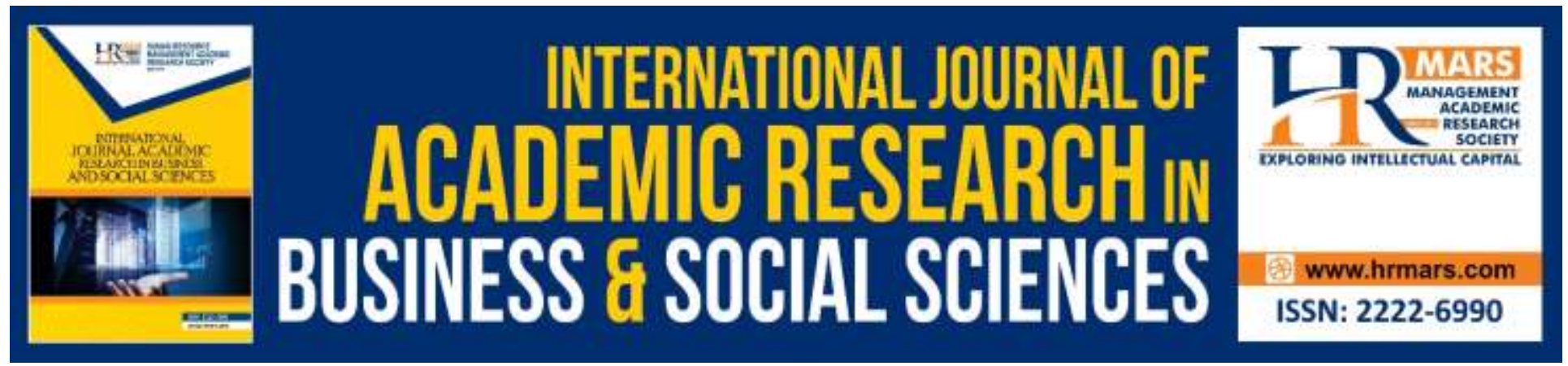

\title{
Factors for Pornography Addiction and its Implication on Teenager Personality
}

\author{
Muhammad Amirul Ashraaf, Nooraini Othman
}

To Link this Article: http://dx.doi.org/10.6007/IJARBSS/v9-i11/6643

DOI: 10.6007/IJARBSS/v9-i11/6643

Received: 05 November 2019, Revised: 20 November 2019, Accepted: 24 November 2019

Published Online: 19 December 2019

In-Text Citation: (Ashraaf, \& Othman, 2019)

To Cite this Article: Ashraaf, M. A., \& Othman, N. (2019). Factors for Pornography Addiction and Its Implication on Teenager Personality. International Journal of Academic Research in Business and Social Sciences, 9(11), 1148-1160.

Copyright: (C) 2019 The Author(s)

Published by Human Resource Management Academic Research Society (www.hrmars.com)

This article is published under the Creative Commons Attribution (CC BY 4.0) license. Anyone may reproduce, distribute, translate and create derivative works of this article (for both commercial and non-commercial purposes), subject to full attribution to the original publication and authors. The full terms of this license may be seen at: http://creativecommons.org/licences/by/4.0/legalcode

Vol. 9, No. 11, 2019, Pg. 1148 - 1160

Full Terms \& Conditions of access and use can be found at http://hrmars.com/index.php/pages/detail/publication-ethics 


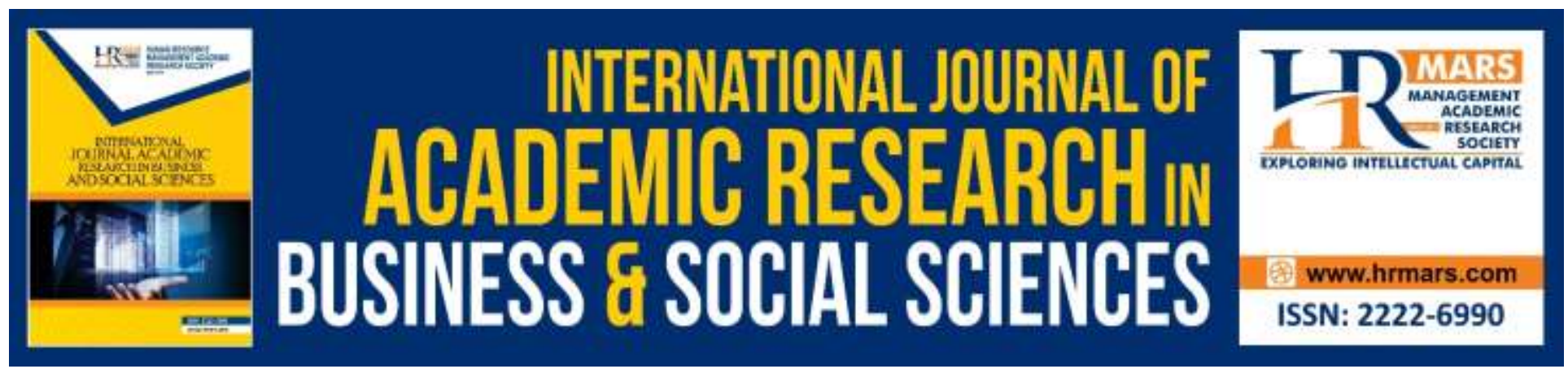

\title{
Factors for Pornography Addiction and its Implication on Teenager Personality
}

\author{
Muhammad Amirul Ashraaf, Nooraini Othman \\ Perdana Centre of Science, Technology \& Innovation Policy, Razak Faculty of Technology \& \\ Informatics, Universiti Teknologi Malaysia \\ Email: ashraaf51@gmail.com, p-noraini@utm.my
}

\begin{abstract}
Addiction to pornography is an act of watching or viewing pornographic material repeatedly which is difficult to dispel by those affected. Pornography addiction among Malaysians not only involves adults but also involves minors such as teenagers. This article aims to discuss the factors that contribute to pornography addiction among teenagers that may be driven by today's technological advances and developments. As a result of analyses from previous studies, most researchers agree that technology is a leading factor in the prevalence of pornography among teenagers today. However, based on the findings of the study, the average researcher focused on the Internet as the only technology that has contributed to pornography addiction without looking at the influence of modern inventions (gadgets) in causing pornography addiction among students. Previous research show that pornography brings about negative implications on the lives and health of those involved. As such, this article provide information and insights for the public, especially parents and students, about the technological factors in adolescent pornography addiction and the negative implications of pornography in life.
\end{abstract}

Keywords: Addiction, Pornography, Technology, Personality, Teenagers

\section{Introduction}

Pornography is an act considered to violate moral values such as exposing or showing off too much of the aurat so much so that it can arouse the desire (lust) to those who see it. Laili (2018) describes pornography as any act or an act that constitutes sexual conduct or sexual exploitation which violates the moral norms of society or acts of extreme exposure of the aurat. According to the Ministry of Health Malaysia the term "pornography" is derived from the word "porneia" which is the Greek word used to refer to prostitutes and the term carries the meaning of writing about prostitutes (MyHEALTH Official Portal of the Ministry of Health Malaysia, 2012). 
Therefore it is understood that pornography is an immoral act which is not accepted in everyday life as it is not only prohibited in the moral sense but also prohibited religions.

Parenting plays a very significant role in shaping children's characters and behaviors. It is so as every action done by the parents (positive or negative) in the presence of the children is a form of indirect education given to the children without the parents being aware that the child will be able to emulate actions done by them. Parents' bad behavior in the presence of children can have a detrimental effect on children's thinking and behaviors. This is for the reason that parents who are supposed to be role models to their children do not display good personalities. For example, the attitudes of parents who use words and display obscene gestures when they are angry can negatively impact their children's behaviors and eventually become trapped in pornographic behaviors that are increasingly affecting teenagers today (Che Noh \& Yusooff, 2011).

The Prophet Muhammad (pbuh) says

"Every baby born is sacred in nature. Parents are the ones who make them Jews, Christians or Magicians" (Bukhari and Muslim History Hadith).

According to this hadith, every human being born into the world is free from all sins and evil and it is the responsibility of every parent to educate their children against the immoral and forbidden nature of religion such as engaging in pornography which is wrong and deemed as a major sin in Islam due to the reason that pornography is a path to the adultery or fornication. Therefore, parents should set good examples for the children such as using polite words, fulfilling religious duties such as performing obligatory prayers, reading the Quran, fasting, giving alms and much more. The reason being a person is more likely to emulate or be influenced by what he or she sees, especially from significant individuals (Bandura, 1977).

\section{Previous Research}

Several studies have been conducted on adolescent involvement in pornographic addiction. Among them is a study by Zakariah \& Baharuddin (2011). This study discusses the challenges that counselors face in helping patients to dispel cyber pornography addiction. The study employs a qualitative mode and some of the important findings are the effects of cybersex, the need for knowledge (understanding the case) and the approaches in treating cybersex addiction. The study also focuses on the approaches in maintaining recovery from cyber-sex addiction to ensure that those who get trapped in pornography will change to become better persons and abandon the habit permanently. Pornography has adverse consequences in life, including family relationships.

In addition, a study on adolescent pornography was also conducted by Wahyu (2016) explains the effects of teen behavior on watching pornography between boys and girls. The study is conducted using a quantitative method involving 300 respondents. It is found that more than $70 \%$ of respondents are exposed to pornography on the Internet which has impacted their adolescent behaviors indirectly and negatively, where they attempt to act out the sex scenes that they watch in pornography. In addition, it is found that pornography also has adverse effects on 
adolescent psychology such as emotional instability, free sex, absence of shyness and other destructive effects on adolescents' lives.

Mass and Dewey (2018), in a study titled Internet Pornography Use among Collagiate Women: Gender Attitudes, Body Monitoring, and Sexual Behavior explain that Internet pornography is a form of oppression on women, whereby pornography indirectly expose women to be potential rape victims and sexual tools for men. According to this study, there is no significant behavioral gap between females who watch porn and those who do not. However, women who do watch pornography tend to engage in free sex and change of partners. However, it is also found that pornography has a positive effect on adolescents, especially regarding knowledge about sex. Although this is a commendable finding, it does not go well with the social, religious and cultural patterns of society in Malaysia where pornography is regarded as immoral and only brings harm to one's life and society.

Manaf et. al., (2013) identify the level of sexual knowledge, resources and experiences of students on matters of sexuality based on demographic factors. The study is conducted based on the quantitative method involving 414 students and the results of the study show that the main sources of knowledge about sex for the students are pornographic videos, magazines, books and pictures containing pornographic elements. The effects of viewing pornographic material have caused many of these students to engage in sexual activities with their partners (unmarried). The findings also show that Malay students are the majority involved in premarital sex. What happens absolutely contradicts the teachings of Islam and Malay culture that prohibit extramarital sex. It is a reliable study in that the data obtained and analyzed are clearly understood.

A study by Vaillancourt \& Bergeron (2018), titled Self-Perceived Problematic Pornography Use: Beyond Individual Differences and Religiosity looked into the effects of pornography on the doer. It is shown that pornography causes extreme addiction, can affect certain aspects of health such as loss of self-control, infertility, loss of respect, dangerous sex (violence) and others. Researchers explain that understanding and practicing the religion is the best way to control one's sexual behavior. Practiving the religion can directly enhance one's moral standing to steer clear from detrimental acts. In this study, it is also found that practicing one's religion is the best way for a person to control one's behavior. The religion preaches its followers not to commit immoral acts which will only bring dishonor to them.

\section{Methodology}

Review on previous relevant literature has been made. Simple thematic analysis approach has been used to identify the factors for pornography addiction as discussed by the previous researchers regarding the similar topic. Several themes have been identified. However, only the main themes are being analyzed and discussed in this paper. The main themes are considered as the most influencing factors given the present technological development. 
INTERNATIONAL JOURNAL OF ACADEMIC RESEARCH IN BUSINESS AND SOCIAL SCIENCES Vol. 9, No. 11, November, 2019, E-ISSN: 2222-6990 @ 2019 HRMARS

\section{Factors for Pornography Addiction}

Several factors that have been identified based on the literature review are discussed as follows:

\section{Technology}

Technology development is very essential to a country as it symbolises the progress of the nation. The purpose of a technology is to solve problems and facilitate any type of work thus making it easier, faster and efficient. However, the use of uncontrolled technology also has negative implications on human life when used for wrong purposes such as online fraud, spreading fake news, hacking and disseminating pornographic materials. Excessive use of technology by children if not well-controlled can leave a negative impact on their lives. For example, on average, children in Malaysia are found to spend between seven and eight hours a day using technologies such as mobile phones, televisions and computers (Nahar et al., 2017).

The negative effects of current technology is noticeable in the behaviours of children and adolescents who are easily influenced by what they see especially through programmess that expose violent and immoral (pornographic) elements. These ultimately lead to their base and violent ways resulting in problems when interacting with others because they cannot distinguish between the real world and fantasy world (Nahar et al., 2017). Hence, it is not surprising that many teenagers today are trapped in pornography addiction. This is because the existing technology makes it easy for them to share and store pornographic videos, pictures and texts without anyone knowing including the parents (Norramazonizni and Haninah, 2016). In fact, the use of technology such as smartphones has made it easier for teenagers who are addicted to pornography to view or watch pornographic videos found in their smartphone storage anytime and anywhere.

Besides, the use of technology such as mobile phones has made it possible for teenagers who are addicted to pornography to use their existing facilities by recording indecent (pornographic) acts with their peers such as those found in pornographic videos and images. In fact, there are people who use technology to record them wearing sexy clothing to promote a product for sale or to gain more followers on social media (Kosmo, 2014). Clearly, the uncontrolled use of technology makes young people vulnerable to pornography which can negatively impact their lives. Therefore, parents should monitor their children's activities to make sure the children are not involved or affected by trivia such as pornography which affects their children's behaviour and health negatively.

For example, parents can limit the use of technology such as smartphones and computers especially among children under the age of 17 by limiting its use for 3 hours to 4 hours per day. Restricting the use of technology among children not only prevents teenagers from becoming addicted to pornography but also guard's children from neglecting their responsibilities as children, students and Muslims. For example, parents can set specific times to allow their children to use gadgets. The results of observations show that this approach is successful not only in controlling the misuse of technology among teenagers such as playing online games or watching pornography but also in changing the teenagers into better persons who appreciate 
time and make good use of gadgets during the allowed time by surfing for useful subject matters apart from shielding them from the health implications of excessive use of technology. Thus, they enjoy better physical health (Agustina et al., 2019).

In addition, Omar and Latip (2016), in their study described several methods that parents can apply in order to have control over the use of technology among their children. One of the suggested methods is to encourage their children to play outside by taking them out and carry out leisure activities and sports. Through sports and recreational activities, children can continue to use technology which encourages motor, physical and mental development. In addition, this study also explains that one of the best ways to monitor the use of technology among teenagers and to protect them from engaging in negative influences is to install panel control software on the computers to block websites that can negatively impact children such as blocking websites of video games, pornography and violent materials.

Obviously, in addition to children, parents should also immerse themselves in the latest technology to ensure that they are always aware of the use of technology by their children. Parental knowledge on the latest technology indirectly enables them to take proactive and effective steps toward using technology among children such as blocking unsafe websites and examining websites or applications used by their children.

\section{The Internet}

The Internet is the most widely used cyber communication system in the world for various purposes such as business, government information systems, entertainment, education etc. Traversing across nations in a short time and at no cost. The power of the Internet has negatively impacted the children of today where they are active only in the virtual world while in reality they are more reserved and lack the social skills with society (Das, et al., 2014). In fact, the Internet is the major source of pornographic materials today, as it has become the fastest growing media in pornography. Various pornographic materials can be downloaded with minimal cost and stored into telecommunications devices such as mobile phones and computers by various sectors of society, both adults and adolescents. Brian et al., (2016), in his study states that the Internet is the source of people's sexual knowledge today, this has indirectly led to the addiction of pornography and sexual acts in society. It only takes a single click through the Google and YouTube apps for one to obtain a variety of pornographic materials be it local or foreign matter. According to Laili (2018), it is found that more than half of Malaysian adolescents nowadays have access to pornographic materials such as pictures, videos or written materials through Internet access which has given to pornography addiction among them today. While it may have been at the early stages of their interest to access pornography is merely for the sake of fun, unknowingly, it is causing serious addiction to them.

In fact, nowadays the Internet is considered a necessity in life as almost every home is now equipped with wireless Internet access. In addition to facilitating day-to-day work and communication, the Internet also enables teenagers to download pornographic materials through their mobile phones which are connected to the Internet. The effects of Internet abuse among adolescents today can be seen where Malaysia is found to be the nation in the Southeast 
Asian region with the highest amount of accessed Internet pornography (Utusan Malaysia, 2018). Based on these statistics, it is evident that the Internet is one of the leading factors in pornography addiction among teenagers today. In addition, a study conducted by Pakianathan (2016) states that the effects of pornography on adolescents in Malaysia are visible from the ages of 13 years old to 18, where these children have begun to engage in sex acts such as holding hands, kissing, groping and having sex with a partner (without a marriage bond).

Therefore, in order to address the problem of pornography among adolescents or children, parents should be aware of what their children are doing, such as examining the sites that their children visit. In addition, parents can also restrict the use of the Internet to their children and also blocking all pornographic sites from their children.

\section{Implications on the Self-esteem of Adolescents}

The impact of pornography addiction on teenagers' personalities involves several aspects:

\section{Pre-marital Sexual Relationships}

In the teaching of Islam, pornography is one of the most forbidden acts as it is an act of zina (zina 'ainun). Pornography is able to provide a powerful stimulant to the point that viewers mimic the scenes they watch in pornographic videos. For example, a study conducted in Indonesia shows that more than $53 \%$ of teenagers who are addicted to pornography end up having sex outside of marriage with their partners, most of whom say that pornography causes them to have sex for pleasure (Aprita \& Yuni, 2015). Based on the statistics shown, it is clear that pornography can cause a person to commit adultery which ultimately leaves detrimental effects on the individual and society such as the births of children out of wedlock and sexual crimes.

In addition, according to statistics from a study conducted in Malaysia it is found that pornography addiction among teenagers starts from as young as 13 years old to 18 years which leads them to behave indecently or to transcend the boundaries of unmarried social relationships such as holding hands with the opposite sex, kissing, groping, wearing revealing body wear and engaging in sex (Ahmad, et al., 2008). This situation has come about due to the actions of young people who are not wise in making decisions due to their high curiosity in doing something new (Abdullah and Saemah, 2015). Thus, it is not surprising that in Malaysia, which is considered a Muslim country and the majority of Malaysians are Muslims, there are many incidence of baby dumping and babies born out of wedlock among the Muslims. These incidents which happen constantly has indirectly tarnished the image of Islam and is attributed to the Muslims themselves.

According to statistics released by the National Registration Department in 2017, a total of 4992 babies were born out-of-wedlock to teenagers aged 18 years and below, of which 120 are reported baby dumping cases and a survey conducted reveals that $22 \%$ of students who gave birth out of wedlock claim their actions are influenced by pornography (Mstar, 2018). According to the statistics, teenagers involved in premarital sex have watched pornographic videos with their partners until they involve themselves in this immoral act. The situation is indeed contrary 
to the customary and cultural values of Malaysian society as a whole which prohibits premarital sex as it defiles and degrades the family institutions. However, due to the disparities that exist today, some groups that claim to fight for human rights cause championed by the western countries which support a culture of free association and free sex, that they consider to be an individual's right that must be upheld. In actual fact, it is a propaganda of the western world to corrupt public opinion around the world (Khadir, 2005).

It is obvious that pornography addiction should not be taken lightly for the reason that it is detrimental to the adolescents who may continue to engage in premarital sex. This is because pornography can negatively affect one's self-control and the brain to commit zina and be influenced by the pseudo-pleasures in pornographic videos. One of the best ways to prevent adolescents from engaging in pornography is to educate them and to encourage them to practice their religion. No religion in the world teaches its followers to do harm.

\section{Family Relationships}

All forms of prohibition in Islam are intended to shape and guide every human being from falling into the valley of perdition and constantly reminding man to always be in subjection to The Almighty Allah the Creator. Therefore, Islam forbids any act that is harmful to human life such as engaging in pornography. Pornography also has negative implications on family relationships such as the relationship between mother and son, husband and wife as well as father and children. Pornography among teenagers that happens now has resulted in the loss of respect for their parents and cause great conflicts in family relationships where incidents like rape occur. In fact, in 2014, police in Kuala Lumpur arrested a 15-year-old teenager on charges of raping his own mother upon her returning home from work (Mstar, August 2014). Investigations by the police show that the teenager committed the act after being influenced by pornographic acts which viewed on his smartphone and computer. It is unimaginable how a son could rape his own mother as a result of the pornographic addiction he experiences. A case such as this proves that pornography addiction among teenagers can ruin family institutions when children lose their respect and are capable of hurting their own parents.

In addition to teenagers being involved in rape cases, pornography has also resulted in teenagers today being involved in cases of incest. Incidents of incest that occur today not only shock the community; it is a reflection of the teenagers today who have low morals and lack of respect towards family members. In contrast to rape, incest is an act of voluntary sexual intercourse (without coercion) by persons who have blood relationships such as mother and son, father and daughter or brother and sister. Islam prohibits incest as it obliterates the respect among family members and can break family lineage by the births of illegitimate children. For example, in January 2019 we were shaken by news of a 14-year-old boy and his 16-year-old sister who were charged in court for engaging in incestuous acts resulting in childbirth (Metro Daily, 2019). Further investigations reveal that the two teenagers were found to be affected by pornographic videos stored in their mobile phones, which eventually led to the strong urge to commit sex with the sibling. 
In addition to the implications of acts of pornography, pornography also has negative implications on family members' communication systems. The use of abusive or profane language such as the use of words that represent bodily parts during anger also affects family relationships. Most of these teenagers use abusive words associated with prostitution, the genitals and body parts, among others, during a fight that result in negative implications on family relationships especially between children and parents and relationships between siblings (Hamzah and Hassan, 2012). It is difficult for a person to control his when speaking out of anger and also his actions that may offend and provoke resentment among family members. Today, some children learn to use profane language based on what they see, read or watch from obscene sources such as pornographic material, and they do not feel guilty or ashamed to use obscene language even when communicating with family members. (Mat Hassan, 2014). The use of foul language by adolescents affects their relationship with family members and their relationships with the surrounding people since the language used reflects the personality, upbringing and morals of the teenagers.

\section{Mental Health}

Good mental health is very important to a person as it enables one to make relevant decisions without being influenced by emotions (negative feelings). The results of previous studies have shown that pornography affects human mental health negatively. Reisman (2008), in her study describes pornography as having a negative effect on the brain of adolescents, which induces them to more likely believe in false impressions (pseudo-sexual pleasures) than the reality of sexual acts which may cause the spread of diseases but also affects their mental health. This is for the reason that pornography can bring about emotional disturbances to adolescents such as having no sense of shame, humiliation and loss of judgement (Norman and Othman, 2019). The most perceptible effect of pornography is on men especially because pornography can prompt a man to imagine a woman's body without clothes or to imagine himself or others having sex (Rahmania and Haryanto, 2017). This occurs for the reason that pornography addiction negatively affects a man's mental health till he loses respect for a woman's dignity.

According to Siti Fatimah, pornography addiction has a negative effect on the development of the human brain at various age levels such as loss of shame, humiliation, depression and others (Daily News, April 1, 2018). Such is the case where pornography causes disturbances to the brain where people who are addicted to pornography tend to keep to themselves rather than socialising with the surrounding community. In fact, the implications of pornography on human mental health are worse than the effects of drug abuse. In contrast to drug addiction, addicts can be treated by administering drugs or arresting drug dealers etc.. Unlike drug addiction, the problem of pornography addiction is more difficult to treat because there are no specific drugs available and pornographic materials are more readily accessible than drugs that makes pornography addiction very difficult to treat. In addition, the effects of pornography addiction to the brain have been found to be similar to the use of illegal substances such as non-prescribed drugs and alcohol use (Reisman, 2008; Yusoff \& Seman, 2018). In addition, health studies have shown that pornography also causes nerve damage to the human brain thus 
weakening the bodily functions and impairs one's memory (Reisman, 2008). Previous research has shown that pornography can weaken a student's memory so that it is difficult to remember what is taught in school. Pornography also causes a person not to perform religious worship. This leads to committing wrongdoings against legal and religion. (Ahmad et al., 2016; Al-Manaseer, Al-Qudah, 2018). Thus, it is evident that pornography addiction is a matter that should be taken seriously and addressed properly as the implications of pornography not only affect the behaviors of those involved but pornography also has a negative impact on human mental health that is difficult to treat despite the prescription of drugs and modern medicines.

\section{Research Gap}

Apart from previous research, this research shows that there is room for future researchers to make improvements or to further research pornography addiction among adolescents that may be conducted by members of the academia and government agencies. Therefore, a number of suggestions are put forward for the purpose. It is hoped that research is done to see role of the law in addressing the addiction to pornography among teenagers today. As it is, apart from education, the law also plays a role in preventing or restraining something that is unethical or illegal from happening in society. In addition, stricter laws can also keep society in check from doing immoral activities. For example, the history of previous civilizations or governments show that the introduction of strict and stringent laws are intended to regulate the behavior of the public and to create a peaceful environment so as to prevent chaos from happening in the country. Therefore, it is hoped that future research will look into how existing laws can play a more significant role to curb pornography addiction among teenagers.

It is also hoped that pornography addiction among adolescents will be studied from a demographic perspective. Demographic surveys are important in order to gauge the percentage of pornography addiction among urban adolescents and adolescents in rural areas. This is to see whether teenagers in urban areas who have more access points are more vulnerable to pornography addiction compared to their counterparts in rural areas. Compared to rural adolescents, teenagers who live in urban areas are less likely to be influenced by pornography because they have a tight schedule as most parents in the city send their children to extra classes to fill their children's time with useful activities like attending extra class, sports training and arts classes (swimming classes, martial arts classes, music classes, etc.).

\section{Conclusion}

The addiction to pornography among adolescents today is closely linked to the progress and development in lifestyles that man enjoy today. Technological advancements in the world today make it possible for people to easily and quickly access pornographic materials especially in the digital form. Exposure to and developments in education also justify why teenagers today are more exposed to the use of technology than their parents to the point of being irresponsible to intentionally access pornography materials on the Internet and are able to bypass cyber barriers to access pornographic materials. The results of the study show that there is no benefit from pornography. In fact, ppornography not only affects one's physical or behavioral state but 
the greatest implications of pornography can be seen in the development of adolescent personality, especially adolescent spiritual development. However, if the existing development is used as much as possible by taking religion (Islam) to be the main ground, it can facilitate the daily lives of the people for many beneficial purposes.

\section{Acknowledgement}

Appreciation to the Ministry of Education Malaysia for the sponsorship under the Fundamental Research Grant Scheme (FRGS 2019), Vot No. 5F018

\section{References}

Manaf, A. R., Hillaluddin A. H., Jamaluddin, Z., Ahmad, N. A., Arshad, F. H., Saad, M. Z., Zain, M. R., \& Abdullah, W. R. K. (2013). Pengetahuan Seksualiti Dalam Kalangan Pelajar Sekolah. Jurnal Pembangunan Sosial. Vol. 16, pp. 15-31.

Abdullah, Z., \& Rahman, S. (2015). Kemahiran Meta-Tingkah Laku dan Kemahiran Membuat Keputusan Pelajar Bermasalah Disiplin dan Tidak Bermasalah Disiplin. Jurnal Pendidikan Malaysia 40(2), pp175-183.

Ahmad, R., \& Jusoh, A. J. (2008). Punca, Kesan Dan Langkah Untuk Menangani Tingkah Laku Seksual Pelajar Mengikut Pendekatan Kaunseling Islam. Konvensyen Pendidikan Nasional.

Lestari, A. Y., Suherni, \& Kusrniyati, Y. (2015). Hubungan Intensitas Mengakses Situs Porno Dengan Perilaku Seksual Pranikah Remaja. Jurnal Kesehatan Ibu dan Anak. Vol ( 7). Indonesia: Yogyakarta.

Agustina, M., Aini, I., Zaina, L., \& Anwar, S. (2019). Pembentukan Pertahanan Diri Anak Dalam Penggunaan Gadget: Strategi Ibu Di Era Digital Untuk Membentuk Anak Yang Handal. Jurnal Pendidikan Agama Islam. Vol. 5 No. 2.

Bandura, A. (1977). Social Learning Theory. New York, NY; General Learning Press.

Brian, Y., Park, G. W., Berger, J., Christman, M., Reina, B., Bishop, F., Warren, P. K. \& Andrew, P. D. (2016). Is Internet Pornography Causing Sexual Dysfunctions? A Review With Clinical Reports. Jornal Behavioral Science.

Noh, C. H., \& Yusooff, F. (2011). Corak Komunikasi Keluarga Dalam Kalangan Keluarga Melayu Di Terengganu. Jurnal Hadhari 3 (2) (2011) 45 - 62. Universiti Kebangsaan Malaysia.

Das, R., \& Bullare, F. (2014). Penggunaan Interner Dan Kesannya Terhadap Kesejahteraan Subjektif Dalam Kalangan Remaja: Perbandingan Peranan Tanggungjawab Jenis-jenis Gaya Keibubapaan. Seminar Kebangsaan Intergriti Keluarga Tunjang Kesejahteraan Masyarakat.

Joibi, N. (2018). 5000 Bayi Lahir Dari Remaja Bawah 18 Tahun. Mstar Online. https://www.mstar.com.my/lokal/semasa/2018/07/23/lahir-bawah-umur.

Kasiman, S. N. F. (2014). Candu Video Lucah. Kosmo. https://umexpert.um.edu.my/file/publication/00003818_65438.pdf.

Kementerian Kesihatan Malaysia. (2012), Pornografi, http://www.myhealth.gov.my/pornografi/. Laili, M. M., Puspitawati, H., \& Yuliati, L. N. (2018). Is Parental Communication or Internet Use That Makes Pornography in Teenagers?, Journal of Child Development Studies, Vol. (03), No. 01, pp59-69. Indonesia: Bogor Agricultural University. 
INTERNATIONAL JOURNAL OF ACADEMIC RESEARCH IN BUSINESS AND SOCIAL SCIENCES

Vol. 9, No. 11, November, 2019, E-ISSN: 2222-6990 @ 2019 HRMARS

Mass, M. K., \& Dewey, S. (2018). Internet Pornography Use Among Collagiate Women: Gender Attitudes, Body Monitoring, and Sexual Behavior. Sage Jounals.

Hassan, M. A. F. (2014). Ketidaksantunan Bahasa Dalam Kalangan Remaja. Serdang: Universiti Putra Malaysia.

Megan, K. M. \& Shannamar, D. (2018). Internet Pornography Use Among Collegiate Women: Gender Attitudes, Body Monitoring, And Sexual Behavior. Jornal Sage.

Arop, M. H. (2019), Remaja Didakwa Sumbang Mahram Dengan Kakak. https://www.hmetro.com.my/utama/2019/01/411815/remaja-didakwa-sumbang-mahramdengan-kakak-metrotv.

Mstar Online. (2014). Remaja 15 Tahun Rogol Ibu Kandung Di Tahan https://www.mstar.com.my/lokal/semasa/2014/08/20/remaja-rogol-ibu/

Norman, M. A. A., \& Othman, N. (2019). Pengaruh Dan Implikasi Tingkah Laku Pornografi Terhadap Kesan Psikologi Dalam Kalangan Remaja Di Malaysia, Persidangan Kaunseling Profesional, Hospital Rehabilitas Cheras.

Nahar, N., Sangi, S., Salvam, B. D., Rosli, N., \& Abdullah, A. H. (2017). Impak Negatif Teknologi Moden Dalam Kehidupan Dan Perkembangan Kanak-Kanak Hingga Usia Remaja. International Journal of Islamic and Civilizational Studies. 01 (2018) pp. 87-99. Universiti Teknologi Malaysia: UTM Press.

Norramazonizni \& Hanina. (2016). Kajian Permasalahan Tingkah Laku Seksual Dalam Kalangan Belia Malaysia. Serdang: Universiti Putra Malaysia.

Omar, S., \& Latip, M. (2016). Pengaruh Peranti Teknologi Kepada Perkembangan Sosial Dan Permasalahan Kesihatan Kanak-Kanak. Universiti Putra Malaysia: Fakulti Sains Pertanian dan Makanan.

Pakianathan, P. Y. (2016). Faktor-Faktor Yang Mempengaruhi Salah Laku Seksual Dalam Kalangan Pelajar Sekolah Menengah. Universiti Pendidikan Sultan Idris: Fakulti Pendidikan Dan Pembangunan Manusia.

Rahmania, T., \& Haryanto, C. H. (2017). Persepsi Pornografi Pada Anak (Studi Pendahuluan Pada Siswa Kelas 5 Sekolah Dasar Islam "X"). Jurnal IImiah Psikologi, Vol. (8) No. 1, pp. 55-74. Indonesia: Universitas Paramadina.

Riesman, J. (2008). Violance and Phornography as Atroctiles of Despair. MIM Moriality in Media Inc. http://www.morialityinmedia.org/index.htm?pornsEffectArticle/clineart.htm.

Shahar, M. F. H. (2018). Ketagihan Pornografi Rosakkan Otak. Berita Harian Online. https://www.bharian.com.my/wanita/keluarga/2018/04/406081/ketagihan-pornografirosakkan-otak.

Bahari, S. N. (2018). Malaysia Paling Tinggi Cari Bahan Pornografi Internet. Utusan Online. http://www.utusan.com.my/berita/nasional/malaysia-paling-tinggi-cari-bahan-pornografidi-internet-1.628212.

Vaillancourt, M. P., \& Bergeron, S., (2018). Self-Perceived Problematic Pornography Use: Beyond Individual Differences and Religiosity. Journal of Springer Nature.

Ningsih, W. (2016). Pengetahuan Dan Sikap Terhadap Video Pornografi Di Internet Dalam Kalangan Remaja. Perak: Universiti Pendidikan Sultan Idris. 
Khadir, W. A. (2005). Globalisasi, Internasionalisasi, Dan Nasionalisme Dalam Mempertahankan Identiti Melayu. Jurnal Pengajian Melayu Jilid 16, Selangor: Pusat Sitasi Malaysia.

Hamzah, Z. A., \& Hassan, M. A. F. (2012). Penggunaan Strategi Ketidaksantunan Dalam Kalangan Remaja Di Sekolah. Jurnal linguistik, Jilid 16.

Zakariah M. Z., \& Baharuddin D. F. (2011) Ketagihan Seks Siber: Pengalaman Kaunselor Di Malaysia. PERKAMA International Convention 2011.

Yusoff, W. M. W., \& Seman, S. C. (2018). Teachers' Knowledge of Higher Order Thinking and Questioning Skills: A Case Study at a Primary School in Terengganu, Malaysia. International Journal of Academic Research in Progressive Education and Development, 7(2), 45-63

Al-Manaseer, D. S., Al-Qudah, A. M. (2018). The Impact of Higher Education Output on Unemployment Rates in Jordan, International Journal of Academic Research in Accounting, Finance and Management Sciences 8 (2): 65-72. 